\title{
The Association between Season and Hypertensive Disorders of Pregnancy: A Systematic Review and Meta-Analysis
}

\author{
Lingyun Liao \\ Department of Obstetrics and Gynecology, West China Second University Hospital, Sichuan University \\ Xiaohong Wei \\ Department of Obstetrics and Gynecology, West China Second University Hospital, Sichuan University \\ Min Liu \\ Department of Obstetrics and Gynecology, West China Second University Hospital, Sichuan University \\ Yijie Gao \\ Department of Obstetrics and Gynecology, West China Second University Hospital, Sichuan University \\ Yangxue Yin \\ Department of Obstetrics and Gynecology, West China Second University Hospital, Sichuan University \\ Rong Zhou ( $\nabla$ zhourong_hx@scu.edu.cn) \\ Department of Obstetrics and Gynecology, West China Second University Hospital, Sichuan University
}

\section{Research Article}

Keywords: Delivery season, Conception season, Hypertensive Disorders of Pregnancy, Preeclampsia, Meta-analysis

Posted Date: November 1st, 2021

DOI: https://doi.org/10.21203/rs.3.rs-1020061/v1

License: (c) (i) This work is licensed under a Creative Commons Attribution 4.0 International License. Read Full License 


\section{Abstract}

Background: There is increasing and inconsistent evidence of a relationship between hypertensive disorders of pregnancy (HDP) and season of delivery or conception.

Methods: Four databases, the Cochrane Library, PubMed, EMBASE and Web of Science, were searched until September 29th, 2021. Two authors extracted data independently. A random effects model and the Mantel-Haenszel method were used to calculate pooled ORs and $95 \%$ Cls.

Results: Twenty articles were included in the systematic review, and 11 articles were included in the meta-analysis. The quantitative analysis of the association between delivery season and HDP showed that the odds of HDP was higher in women who deliver in winter than in those who delivered in summer $(\mathrm{OR}=1.18,95 \% \mathrm{Cl} 1.02-1.38, \mathrm{p}<0.001)$ and all other seasons $(\mathrm{OR}=1.17,95 \% \mathrm{Cl} 1.03-1.34, \mathrm{p}<0.001)$. In the qualitative analysis of the association between conception season and HDP, 4 of 7 studies suggested that women who conceived in summer had a higher risk of HDP than those who conceived in other seasons.

Conclusions: Based on the evidence to date, we found weakly positive relationships between HDP and summer conception and winter delivery.

\section{Background}

Hypertensive disorders of pregnancy (HDP) is a common obstetric disease, occurring in $5 \%-10 \%$ of all pregnancies and accounting for $10 \%-16 \%$ of total pregnancy-related deaths; it is the leading cause of maternal death $(1,2)$. HDP not only has short-term impacts during pregnancy but also longterm impacts on the health of mothers and their offspring, potentially causing maternal coronary heart disease, stroke and hypertension in offspring (3-5). At present, the precise etiology of HDP is unclear and is considered to be the result of the interaction between genes and the environment. However, a number of risk factors have been demonstrated, such as older age, low maternal educational status and multiple pregnancies (6, 7).

Seasonal changes affect the occurrence and development of many diseases, such as cardiovascular diseases and autoimmune diseases (8, 9). Similarly, seasonal changes also increased the risk of maternal and neonatal mortality and the incidence of delivery complications (10). HDP deserves our attention because some studies have reported that HDP is associated with season, but the findings have been inconsistent. Some researchers reported that the prevalence rates of gestational hypertension and preeclampsia were higher in women who delivered in winter and conceived in summer $(7,11)$. However, some studies found no association with season $(6)$ or found an opposite result (12).

It is important to synthesize such findings to determine which season or month of delivery or conception is related to HDP to facilitate HDP management and interventions targeting high-risk groups.

\section{Methods}

The Meta-Analysis of Observational Studies in Epidemiology (MOOSE) (13) and Preferred Reporting Items for Systematic review and Meta-Analyses (PRISMA) (14) guidelines were followed for this systematic review and meta-analysis. This study did not require ethical approval or patient consent.

\section{Search strategy}

Four databases, the Cochrane Library, PubMed, EMBASE and Web of Science, were searched until September 29 th, 2021 by two independent authors ( $L L$ and XW). Medical Subject Headings (MeSH) terms combined with free text were used to identify studies on associations between seasons and HDP. The detailed search terms of PubMed can be found in Table 1 and appropriate adjustments were made in other databases. Furthermore, we manually searched the citations of the included articles to prevent omission. After retrieval, we used the Endnote X9 library (Clarivate Analytics, Philadelphia, PA, USA) to check for duplicates and manage references.

Table 1

Search strategy for PubMed. 


\begin{tabular}{|lll|}
\hline \multicolumn{2}{|c|}{ Outcome: Hypertensive Disorders of Pregnancy } \\
\hline$\# 1$ & MeSH terms & "hypertension, pregnancy induced"[MeSH Terms] OR "pre eclampsia"[MeSH Terms] OR "Eclampsia"[MeSH Terms] \\
\hline \#2 & Title/Abstract & $\begin{array}{l}\text { "hypertension pregnancy induced" OR "pregnancy induced hypertension" OR "gestational hypertension" OR "hypertension } \\
\text { gestational" OR "transient hypertension pregnancy" OR "pregnancy transient hypertension" OR "pregnancy hypertension" } \\
\text { OR "hypertension in pregnancy" OR "pre eclampsia" OR "Preeclampsia" OR "pregnancy toxemias" OR "pregnancy toxemia" } \\
\text { OR "edema proteinuria hypertension gestosis" }\end{array}$ \\
\hline \#3 & \#1 OR \#2 & \\
\hline Exposure: season & MeSH terms & $\begin{array}{l}\text { "seasons"[MeSH Terms] OR "climate"[MeSH Terms] OR "meteorology"[MeSH Terms] OR "weather"[MeSH Terms] OR } \\
\text { "temperature"[MeSH Terms] }\end{array}$ \\
\hline \#5 & Title/Abstract & $\begin{array}{l}\text { "season*" OR "summer" OR "spring" OR "autumn" OR "winter" OR "climat*" OR "meteorology*" OR "weather*" OR } \\
\text { "temperatur*" OR "Cold" OR "frigidity" OR "Hot" OR "Heat" }\end{array}$ \\
\hline \#6 & \#4 OR \#5 & \\
\hline \#7 & \# AND \#6 & \\
\hline
\end{tabular}

\section{Selection criteria}

\section{Inclusion criteria}

1) The exposure of interest was season or month.

2) The investigation outcome was HDP.

3) The study design was a case-control, cohort or cross-sectional design.

4) Odds ratios (ORs) and $95 \%$ confidence intervals ( $95 \% \mathrm{Cls})$ or relevant data that could be computed were provided

\section{Exclusion criteria}

1) Studies on season or month of admission.

2) Studies for which the full text could not be downloaded.

3) Studies that were not published in English.

\section{Data extraction and quality assessment}

We designed a data extraction table during the full-text review stage. Two authors (LL and XW) extracted the data independently. The information recorded included first author, published year, study region, research type, sample size, study period, exposure definition, and outcome definition. We also recorded adjusted ORs and 95\% Cls or crude ORs and 95\% Cls from the original data if provided. If necessary, authors were contacted for additional details or figure data.

Based on the UK's official weather service definition, March is regarded as the beginning of spring, and spring, summer, autumn and winter are defined in three-months increments (15). When the study country or region was in the Southern Hemisphere, we adjusted the seasons accordingly. We used Google maps to estimate the average latitudes of countries and regions (16).

If a disagreement arose, we consulted a third author (RZ) or discussed until consensus was reached. Only studies that had sufficient data for calculation were included in the meta-analysis.

Study quality was evaluated by two author (LL and XW) with the Newcastle-Ottawa quality assessment scale (NOS) (17), which includes three categories and eight items, with a total score of nine. A NOS score of seven or higher indicated high quality.

\section{Statistical analysis}


Stata/SE 15.1 (StataCorp, College Station, TX, USA) was used for the quantitative analysis. In studying the relationship between season of delivery and preeclampsia, summer was chosen as the reference month because most previous studies suggested that the prevalence associated with summer delivery was low $(7,18-21)$. Similarly, winter was chosen as the reference season in the analysis of conception season (22-26).

A random effects model and the Mantel-Haenszel method were used to calculated pooled ORs and 95\% Cls. ORs were displayed using a forest plot. Heterogeneity was estimated by the Cochrane Q statistic ( $p<0.1$ indicates the existence of heterogeneity) and inconsistency index $\left(\mathrm{I}^{2}\right)$ (low: $25-50 \%$; moderate: $50-75 \%$; high: 75-100\%). To explore the source of heterogeneity, subgroup analyses and sensitivity analyses were performed. Subgroup analyses were performed according to sample size, latitude, income group and whether multiple pregnancies were included. In addition, we used a stepwise elimination method to perform the sensitivity analysis and verify the robustness of the results. Begg's funnel plot and Egger's test were used to check for the risk of publication bias.

\section{Results}

\section{Study selection}

Figure 1 shows the literature selection process in detail. A total of 2759 studies were retrieved for further screening based on the established selection criteria. After removing duplicates, the titles and abstracts of 2140 studies were screened, and 2007 unqualified studies were excluded. Finally, we screened the full texts of the remaining and excluded 113 unqualified studies. Consequently, 20 studies were included in the systematic review (6, 7 , $11,12,18-33)$, and 11 studies with sufficient quantitative data were included in the meta-analysis $(6,7,18-21,27-31)$.

\section{Study characteristics and quality assessment}

Table 2 shows the detailed descriptions and quality assessments of all the studies included in the review. Studies were carried out in 7 countries, all from the Northern Hemisphere, with different latitudes. All disease-related data was extracted from medical records. Fourteen studies reported the relationship between delivery season or month and $\operatorname{HDP}(6,7,11,18-21,26-32)$, while seven studies reported the relationship between conception season or month and $\operatorname{HDP}(12,22-26,33)$. The outcome definition was not completely uniform. Some studies focused on comprehensive HDP, while other studies focused on only severe preeclampsia. Using the quality assessment guidelines (17), seventeen studies were considered to be high quality (score of 7 or more). Three articles scored six points because they lacked ample control of confounding factors, such as singleton pregnancy or maternal-related disease history. 
Table 2

Characteristics of the included studies.

\begin{tabular}{|c|c|c|c|c|c|c|c|c|c|c|}
\hline Author & $\begin{array}{l}\text { Publication } \\
\text { year }\end{array}$ & Study region & $\begin{array}{l}\text { Study } \\
\text { design }\end{array}$ & Period & Total/case (n) & $\begin{array}{l}\text { Exposure } \\
\text { definition }\end{array}$ & $\begin{array}{l}\text { Outcome } \\
\text { definition }\end{array}$ & Latitude & $\begin{array}{l}\text { Income } \\
\text { group }\end{array}$ & NOS \\
\hline $\begin{array}{l}\text { Rohr } \\
\text { Thomsen } \\
\text { et al. }\end{array}$ & 2020 & Denmark & cohort & $\begin{array}{l}1989- \\
2010\end{array}$ & $50665 / 4285$ & $\begin{array}{l}\text { Month of } \\
\text { conception }\end{array}$ & HDP & Middle & High & 8 \\
\hline $\begin{array}{l}\text { Farzaneh } \\
\text { et al. }\end{array}$ & 2019 & $\begin{array}{l}\text { Sistan and } \\
\text { Baluchestan, } \\
\text { Iran }\end{array}$ & $\begin{array}{l}\text { nested } \\
\text { case- } \\
\text { control }\end{array}$ & 2017 & $540 / 270$ & $\begin{array}{l}\text { Season of } \\
\text { delivery }\end{array}$ & Preeclampsia & Low & Middle & 7 \\
\hline $\begin{array}{l}\text { Shayan et } \\
\text { al. }\end{array}$ & 2019 & $\begin{array}{l}\text { Hamadan, } \\
\text { Iran }\end{array}$ & $\begin{array}{l}\text { case- } \\
\text { control }\end{array}$ & $\begin{array}{l}2005- \\
2015\end{array}$ & $1458 / 729$ & $\begin{array}{l}\text { Season of } \\
\text { conception }\end{array}$ & Preeclampsia & Middle & Middle & 6 \\
\hline $\begin{array}{l}\text { Weinberg } \\
\text { et al. }\end{array}$ & 2017 & Norway & cohort & $\begin{array}{l}1999- \\
2009\end{array}$ & $356662 / 13959$ & $\begin{array}{l}\text { Month of } \\
\text { conception }\end{array}$ & $\begin{array}{l}\text { Preeclampsia } \\
\text { and } \\
\text { eclampsia }\end{array}$ & High & High & 8 \\
\hline Li et al. & 2016 & $\begin{array}{l}\text { Hunan, } \\
\text { China }\end{array}$ & cohort & $\begin{array}{l}2010- \\
2011\end{array}$ & $6223 / 449$ & $\begin{array}{l}\text { Season of } \\
\text { delivery }\end{array}$ & Preeclampsia & Middle & Middle & 7 \\
\hline Ali et al. & 2015 & Sudan & $\begin{array}{l}\text { case- } \\
\text { control }\end{array}$ & $\begin{array}{l}2008- \\
2010\end{array}$ & $306 / 153$ & $\begin{array}{l}\text { Month of } \\
\text { delivery }\end{array}$ & HDP & Low & Low & 7 \\
\hline Tran et al. & 2015 & Paris, France & cohort & $\begin{array}{l}2008- \\
2011\end{array}$ & $63633 / 526$ & $\begin{array}{l}\text { Season of } \\
\text { conception }\end{array}$ & $\begin{array}{l}\text { Severe } \\
\text { preeclampsia }\end{array}$ & Middle & High & 8 \\
\hline $\begin{array}{l}\text { Morikawa } \\
\text { et al. }\end{array}$ & 2014 & Japan & cohort & $\begin{array}{l}2005- \\
2009\end{array}$ & $301501 / 13848$ & $\begin{array}{l}\text { Month of } \\
\text { delivery }\end{array}$ & HDP & Middle & High & 8 \\
\hline Luo et al. & 2013 & $\begin{array}{l}\text { Sichuan, } \\
\text { China }\end{array}$ & $\begin{array}{l}\text { case- } \\
\text { control }\end{array}$ & $\begin{array}{l}2007- \\
2010\end{array}$ & $1300 / 650$ & $\begin{array}{l}\text { Season of } \\
\text { delivery }\end{array}$ & Preeclampsia & Middle & Middle & 7 \\
\hline $\begin{array}{l}\text { Wellington } \\
\text { et al. }\end{array}$ & 2012 & Texas, USA & cohort & 2001 & $31207 / 12481$ & $\begin{array}{l}\text { Season of } \\
\text { delivery }\end{array}$ & $\begin{array}{l}\text { Preeclampsia } \\
\text { and } \\
\text { eclampsia }\end{array}$ & Middle & High & 7 \\
\hline $\begin{array}{l}\text { Rylander } \\
\text { et al. }\end{array}$ & 2011 & Sweden & cohort & $\begin{array}{l}1990- \\
1994\end{array}$ & $482659 / 182$ & $\begin{array}{l}\text { Season of } \\
\text { delivery }\end{array}$ & Eclampsia & High & High & 8 \\
\hline $\begin{array}{l}\text { Bullock et } \\
\text { al. }\end{array}$ & 2011 & $\begin{array}{l}\text { Oklahoma, } \\
\text { USA }\end{array}$ & cohort & $\begin{array}{l}2005- \\
2007\end{array}$ & $3050 / 176$ & $\begin{array}{l}\text { Month of } \\
\text { delivery }\end{array}$ & Preeclampsia & Middle & High & 6 \\
\hline Tam et al. & 2008 & $\begin{array}{l}\text { Hong Kong, } \\
\text { China }\end{array}$ & cohort & $\begin{array}{l}1995- \\
2002\end{array}$ & $15402 / 245$ & $\begin{array}{l}\text { Season of } \\
\text { conception }\end{array}$ & $\begin{array}{l}\text { Preeclampsia } \\
\text { and } \\
\text { eclampsia }\end{array}$ & Low & Middle & 8 \\
\hline $\begin{array}{l}\text { Soroori et } \\
\text { al. }\end{array}$ & 2007 & Gilan, Iran & $\begin{array}{l}\text { cross- } \\
\text { sectional }\end{array}$ & $\begin{array}{l}1999- \\
2001\end{array}$ & $12142 / 397$ & $\begin{array}{l}\text { Season of } \\
\text { delivery }\end{array}$ & Preeclampsia & Middle & Middle & 7 \\
\hline $\begin{array}{l}\text { Rudra et } \\
\text { al. }\end{array}$ & 2005 & $\begin{array}{l}\text { Washington, } \\
\text { USA }\end{array}$ & $\begin{array}{l}\text { cross- } \\
\text { sectional }\end{array}$ & $\begin{array}{l}1987- \\
2001\end{array}$ & $83228 / 6680$ & $\begin{array}{l}\text { Month of } \\
\text { conception }\end{array}$ & Preeclampsia & Middle & High & 7 \\
\hline $\begin{array}{l}\text { Phillips et } \\
\text { al. }\end{array}$ & 2004 & $\begin{array}{l}\text { Vermont, } \\
\text { USA }\end{array}$ & $\begin{array}{l}\text { case- } \\
\text { control }\end{array}$ & $\begin{array}{l}1995- \\
2003\end{array}$ & $7904 / 142$ & $\begin{array}{l}\text { Season of } \\
\text { conception } \\
\text { and } \\
\text { delivery }\end{array}$ & Preeclampsia & Middle & High & 7 \\
\hline $\begin{array}{l}\text { Magnus et } \\
\text { al. }\end{array}$ & 2001 & Norway & cohort & $\begin{array}{l}1967- \\
1998\end{array}$ & $1869388 / 51801$ & $\begin{array}{l}\text { Month of } \\
\text { delivery }\end{array}$ & Preeclampsia & High & High & 7 \\
\hline $\begin{array}{l}\text { Makhseed } \\
\text { et al. }\end{array}$ & 1999 & Kuwait & $\begin{array}{l}\text { case- } \\
\text { control }\end{array}$ & $\begin{array}{l}1992- \\
1994\end{array}$ & $26805 / 692$ & $\begin{array}{l}\text { Month of } \\
\text { delivery }\end{array}$ & Preeclampsia & Low & High & 6 \\
\hline Ros et al. & 1998 & Sweden & cohort & $\begin{array}{l}1987- \\
1993\end{array}$ & $10193 / 557$ & $\begin{array}{l}\text { Season of } \\
\text { delivery }\end{array}$ & Eclampsia & High & High & 8 \\
\hline $\begin{array}{l}\text { Jamelle et } \\
\text { al. }\end{array}$ & 1998 & Pakistan & $\begin{array}{l}\text { case- } \\
\text { control }\end{array}$ & 1996 & $18878 / 395$ & $\begin{array}{l}\text { Month of } \\
\text { delivery }\end{array}$ & Eclampsia & Low & Middle & 6 \\
\hline
\end{tabular}

\section{Season of delivery and HDP}

Fourteen articles assessed the relationship between delivery season and $\operatorname{HDP}(6,7,11,18-21,26-32)$, and eleven articles with sufficient data were included in the meta-analysis $(6,7,18-21,27-31)$. Because the heterogeneity between studies was high $\left(p<0.1,1^{2}>25 \%\right)$, we used a random effects model to pool the ORs and $95 \% \mathrm{Cls}$. 
With summer delivery as the reference, a significant association between HDP and winter delivery $(\mathrm{OR}=1.18,95 \% \mathrm{Cl} 1.02-1.38, p<0.001)$ was found, but there was no association with spring delivery $(\mathrm{OR}=1.09,95 \% \mathrm{Cl} 0.97-1.22, p=0.066)$ or fall delivery $(\mathrm{OR}=1.01,95 \% \mathrm{Cl} 0.92-1.11, p=0.189)$ (Figure 2).

Subgroup analyses were carried out according to latitude, income group, sample size, and whether multiple pregnancies were excluded in the studies. The results of the associations of HDP with winter delivery and summer delivery were as follows. In the latitude subgroup analysis (Figure 3 ), the heterogeneity decreased slightly (high latitude: $I^{2}=42.6 \%, p=0.187$; middle latitude: $I^{2}=67.2 \%, p=0.016$; low latitude: $I^{2}=0.0 \%, p=0.931$ ), and a stronger association was observed in high-latitude countries $(\mathrm{OR}=1.62,95 \% \mathrm{Cl} 1.20-2.20)$ and middle-latitude countries $(\mathrm{OR}=1.24,95 \% \mathrm{Cl} 1.00$ 1.55). However, at low latitudes, the result was nonsignificant ( $\mathrm{OR}=0.90,95 \% \mathrm{Cl} 0.76-1.05)$. When stratified by income group and excluding studies with a sample size $<10,000$, the heterogeneity did not change considerably, and the correlation between HDP and winter delivery remained positive. In 2 studies excluding women with multiple pregnancies, the studies by $\mathrm{Li}(\mathrm{OR}=1.56,95 \% \mathrm{Cl} 0.91-2.69)$ and $\mathrm{Rylander}(\mathrm{OR}=1.99,95 \% \mathrm{Cl} 1.33-2.98)$ still showed significant associations between HDP and winter delivery $(7,21)$. The results of the subgroup analyses for spring and fall delivery versus summer delivery were nonsignificant.

The sensitivity analysis suggested that no single study altered the association (Figure 4). In the publication bias test, three Begg's funnel plots were symmetric, and Egger's test was nonpositive (winter $p=0.175$; spring $p=0.454$; fall $p=0.623$ ) (Figure 5).

Based on the above results, we further compared winter delivery with delivery in other seasons. The result yielded a statistically significant result (OR $=1.17,95 \% \mathrm{Cl} 1.03-1.34, \mathrm{I}^{2}=75.4 \%, p<0.001$ ) (Figure 6). Subgroup analysis did not significantly reduce the interstudy heterogeneity. The results of the sensitivity analysis were stable. Symmetrical Begg's funnel plots and Egger's test $(p=0.155)$ showed that there was no publication bias.

Two of the remaining three studies that were not included in the quantitative analysis revealed that the risk of HDP was highest when women delivered in the winter months $(11,32)$, which was consistent with our quantitative analysis. Morikawa reported that the relative risks of pregnancyinduced hypertension were 1.12 (95\% Cl 1.06-1.19) for delivery in January-February and 1.16 (95\% Cl 1.09-1.22) for delivery in March-April compared with delivery in July- August (11). Magnus reported that delivery in August was associated with the lowest risk of preeclampsia, while the risk was highest in the winter months (for December, adjusted OR $=1.26,95 \% \mathrm{Cl} 1.20-1.31$ ) (32). However, Phillips found that there were no significant differences in the rates of preeclampsia in women with winter and spring deliveries, but women with summer deliveries $(\mathrm{OR}=0.63,95 \% \mathrm{Cl}$ $0.39-0.99$ vs. spring) and fall deliveries ( $\mathrm{OR}=0.60,95 \% \mathrm{Cl} 0.37-0.98$ vs. spring) had reduced odds of developing preeclampsia (26).

\section{Season of conception and HDP}

Seven studies assessed the relationship between conception season or month and HDP. Four studies supported that conception in summer increased the risk of developing $\operatorname{HDP}(22,24-26)$.

Rohr Thomsen showed that women who conceived in August (OR $=1.35,95 \% \mathrm{Cl} 1.11-1.64)$ had the highest risk of gestational hypertension, and those who conceived in June $(\mathrm{OR}=1.17,95 \% \mathrm{Cl} 0.94-1.45)$ had the highest risk of preeclampsia, which occurred in both the summer months (22). Tran found that conception in summer was associated with the highest risk of severe preeclampsia $(\mathrm{OR}=1.53,95 \% \mathrm{Cl} 1.27-1.85, \mathrm{vs}$. winter) $(24)$. Tam (OR $=1.7,95 \% \mathrm{Cl} 1.2-2.5$, vs. autumn) and Phillips (OR $=1.7,95 \% \mathrm{Cl} 1.1-2.8$ vs. spring) revealed that conception in summer was associated with an increased risk of preeclampsia $(25,26)$.

However, the results of 3 studies were not consistent with the above conclusion. Rudra reported that conception in February (OR $=1.17,95 \% \mathrm{Cl} 1.03-$ 1.33 vs. January) and April ( $\mathrm{OR}=1.18,95 \% \mathrm{Cl} 1.03-1.34$ vs. January) through August $(\mathrm{OR}=1.14,95 \% \mathrm{Cl} 1.01-1.30$ vs. January) were associated with significantly higher risks of preeclampsia (33). However, Shayan found that conception in autumn increased the odds of preeclampsia (OR $=1.13$, $95 \% \mathrm{Cl} 0.73-1.76$, vs. winter) and that conception in summer was associated with the lowest odds of preeclampsia (OR $=0.26,95 \% \mathrm{Cl} 0.17-0.38, \mathrm{vs}$. winter) (12). Weinberg revealed that women who conceived in spring had a higher risk of HDP, while those that conceived in autumn had a lower risk (23).

\section{Discussion}

\section{Main findings}

This systematic review of 20 studies and meta-analysis of 11 studies explored the relationship between season and the development of hypertensive pregnancy disorders. The results showed increased odds of HDP in women who delivered in winter compared with those who delivered in summer $(\mathrm{OR}=1.18,95 \% \mathrm{Cl} 1.02-1.38, p<0.001)$ and other seasons $(\mathrm{OR}=1.17,95 \% \mathrm{Cl} 1.03-1.34, p<0.001)$. Furthermore, in the analysis of the relationships between HDP and seasons or months of conception, 4 of 7 studies reported that women who conceived in summer had a higher risk of HDP.

Some studies have suggested that HDP may be more strongly associated with conception time than with delivery time (26, 34). Although the stages of pregnancy in the included studies were different, we combined them by gestation period. For example, in the studies on delivery and conception 
months, women who conceived in hot months generally delivered in cold months in the following year $(11,18,22,27,32)$. Women who conceived in June and delivered in March had the highest risk of preeclampsia (22). The differences in these study results studies were possibly associated with premature delivery in women with HDP and the miscalculation of conception time. First, many studies have reported that women with HDP are prone to premature delivery (35-37), and low-dose aspirin could decrease the incidence of preterm birth, particularly if initiated before 16 weeks of gestation (36). Therefore, this could help explain the high incidence of HDP in women who conceived in summer and delivered in winter. Second, a lack of ultrasound examination to determine the date of conception or the presence of menstrual disorders may cause inaccurate estimates of the date of conception, resulting in less accurate conclusions about the relationship between HDP and month of conception (25, 33).

Based on our analysis, it was not possible to explain how season factors could affect the onset of HDP. According to basic research and epidemiological investigations, a number of possible mechanisms influenced by factors such as nutritional status, sunlight exposure, temperature, humidity, and infection, may explain the correlation. Here, we discuss some relevant factors. Among the different seasons, there is wide variation in the nutrients consumed by people, resulting in different risks of pregnancy-related diseases (38). Lowensohn reported that calcium supplementation may reduce the risk of HDP, especially in low-calcium populations (38). In addition, Mirzakhani reported that vitamin D levels above $30 \mathrm{ng} / \mathrm{ml}$ at the start of the trial and in late pregnancy were associated with a lower risk of preeclampsia (39). Vitamin D levels are not only affected by seasonal variations in nutrient intake but are also closely related to sunlight exposure. Vitamin $\mathrm{D}$ is produced naturally in the skin when skin is exposed to sunlight, which varies greatly among seasons $(18,21,22)$. In a recent study by Horton-French, young adults had a 3 times higher risk of vitamin D deficiency in the winter than in the summer, which was consistent with our findings of a higher risk in women who delivered in winter (40). Additionally, variations in temperature and humidity have also been hypothesized. Xiong reported that in the early stages of pregnancy, cold temperatures reduced the risk, whereas hot temperatures increased the risk (34). Moreover, the incidence of preeclampsia was significantly higher during the dry season than during the rainy season $(41,42)$. As a possible explanation, Krininger reported that heat shock was found to compromise embryo implantation in an animal model (43). Water loss resulting in reduced plasma volume in warm months may increase the risk of developing preeclampsia (44), which may indirectly explain the increased risk of HDP in women who conceive in summer. Exposure to cold temperatures could lead to vasospasms and subsequent ischemia (45), which is a possible reason for the increased risk of HDP in winter (20). All of these factors that affect cardiovascular conditions may together increase blood pressure, promoting the formation of HDP. Finally, seasonal fluctuations in infection rates may result in variability in the seasonal occurrence of preeclampsia (46), which could cause a maternal systemic inflammatory response.

In this meta-analysis of studies on delivery season and conception season, the heterogeneity was high, possibly due to confounding factors such as sample size, latitude, income group, study design, and definitions of outcomes. To solve this problem, we performed subgroup analyses to find the source of the heterogeneity. The heterogeneity slightly decreased in only the latitude subgroup analysis. Although we failed to find the major source of heterogeneity, our sensitivity analysis indicated that our results were valid. In addition, because reference seasons or months were different and some original data could not be obtained, we failed to carry out a meta-analysis of studies on conception season and HDP. Therefore, more studies need to be analyzed to minimize heterogeneity and explore the relationship between conception season and HDP to obtain more accurate correlation results.

In summary, additional large-scale multicenter studies analyzing specific seasonal factors, such as temperature, humidity and pollution, are needed to thoroughly study the relationship between season or month and HDP. Furthermore, the identification of risk factors for the onset of HDP is important because it could greatly improve pregnancy and fetal outcomes.

\section{Strengths and limitations}

Accurate and robust statistical results were reported in this meta-analysis on the positive association between season and HDP. In addition, this is the first quantitative analysis of this topic.

However, this study has some limitations. First, we found heterogeneity in our meta-analysis. Many factors beyond our control, such as sample size, latitude, income group, study design, and definitions of outcomes, could all affect the degree of heterogeneity. Thus, additional high-quality studies are needed to reduce heterogeneity in the future. Second, in the study of the relationship between conception season and HDP, the reference season or month differed, and original data were not reported. This caused difficulty in performing a meta-analysis, resulting in insufficient reliability of the results. Third, we excluded non-English articles, which led to the exclusion of studies not published in English, potentially influencing the representativeness of our results.

\section{Conclusion}

Based on the evidence to date, we found weakly positive relationships between HDP and summer conception and winter delivery. Additional largescale multicenter studies analyzing detailed seasonal factors, such as temperature, humidity and pollution, are needed to thoroughly study the relationship between season or month and HPD.

\section{Abbreviations}


HDP : Hypertensive disorders of pregnancy

MOOSE : The Meta-Analysis of Observational Studies in Epidemiology

PRISMA : Preferred Reporting Items for Systematic review and Meta-Analyses

MeSH : Medical Subject Headings

ORs :Odds ratios

95\% Cls: $95 \%$ confidence intervals

NOS : the Newcastle-Ottawa quality assessment scale

\section{Declarations}

\section{Availability of data and materials}

Data will be available from the corresponding author upon reasonable request.

\section{Acknowledgements}

Not applicable.

\section{Funding}

This work was supported by the National Natural Science Foundation of China (No. 81571465 and 81871175) and the Key Projects of Sichuan Science and Technology Department (No. 2021YFS0208).

\section{Author information}

\section{Affiliations}

Department of Obstetrics and Gynecology, West China Second University Hospital, Sichuan University, Key Laboratory of Birth Defects and Related Diseases of Women and Children (Sichuan University) of Ministry of Education, Chengdu, Sichuan, China

Lingyun Liao, Xiaohong Wei, Min Liu, Yijie Gao, Yangxue Yin \& Rong Zhou

\section{Contributions}

LL and XW performed experiments and analyzed the results. LL conceived the study and prepared the manuscript. ML modified the figure. YG, YY and RZ supervised the study. All authors contributed to the article and approved the submitted version.

\section{Corresponding author}

Rong Zhou

\section{Ethics declarations}

\section{Ethics approval and consent to participate}

Not applicable.

\section{Consent for publication}

Not applicable. 


\section{Competing interests}

The authors declare that they have no competing interests.

\section{References}

1. Hypertension in pregnancy. Report of the American College of Obstetricians and Gynecologists' Task Force on Hypertension in Pregnancy. Obstet Gynecol. 2013;122(5):1122-31.

2. Umesawa M, Kobashi G. Epidemiology of hypertensive disorders in pregnancy: prevalence, risk factors, predictors and prognosis. Hypertens Res. 2017;40(3):213-20.

3. Malek AM, Wilson DA, Turan TN, Mateus J, Lackland DT, Hunt KJ. Maternal Coronary Heart Disease, Stroke, and Mortality Within 1, 3, and 5 Years of Delivery Among Women With Hypertensive Disorders of Pregnancy and Pre-Pregnancy Hypertension. J Am Heart Assoc. 2021:e018155.

4. Countouris ME, Villanueva FS, Berlacher KL, Cavalcante JL, Parks WT, Catov JM. Association of Hypertensive Disorders of Pregnancy With Left Ventricular Remodeling Later in Life. J Am Coll Cardiol. 2021;77(8):1057-68.

5. Kurbasic A, Fraser A, Mogren I, Hallmans G, Franks PW, Rich-Edwards JW, et al. Maternal Hypertensive Disorders of Pregnancy and Offspring Risk of Hypertension: A Population-Based Cohort and Sibling Study. Am J Hypertens. 2019;32(4):331-4.

6. Farzaneh F, Tavakolikia Z, Soleimanzadeh Mousavi SH. Assessment of occurrence of preeclampsia and some clinical and demographic risk factors in Zahedan city in 2017. Clin Exp Hypertens. 2019;41(6):583-8.

7. Li X, Tan H, Huang X, Zhou S, Hu S, Wang X, et al. Similarities and differences between the risk factors for gestational hypertension and preeclampsia: A population based cohort study in south China. Pregnancy Hypertens. 2016;6(1):66-71.

8. Watad A, Azrielant S, Bragazzi NL, Sharif K, David P, Katz I, et al. Seasonality and autoimmune diseases: The contribution of the four seasons to the mosaic of autoimmunity. J Autoimmun. 2017;82:13-30.

9. Stewart S, Keates AK, Redfern A, McMurray JJV. Seasonal variations in cardiovascular disease. Nat Rev Cardiol. 2017;14(11):654-64.

10. Rylander C, Odland J, Sandanger TM. Climate change and the potential effects on maternal and pregnancy outcomes: an assessment of the most vulnerable-the mother, fetus, and newborn child. Glob Health Action. 2013;6:19538.

11. Morikawa M, Yamada T, Yamada T, Cho K, Sato S, Minakami H. Seasonal variation in the prevalence of pregnancy-induced hypertension in Japanese women. J Obstet Gynaecol Res. 2014;40(4):926-31.

12. Shayan A, Sourinejad H, Refaei M, Masoumi SZ, Tapak L, Soltani F. Predictors of Preeclampsia Based on a 10-Year Case-Control Study. J Family Reprod Health. 2019;13(1):14-20.

13. Stroup DF, Berlin JA, Morton SC, Olkin I, Williamson GD, Rennie D, et al. Meta-analysis of observational studies in epidemiology: a proposal for reporting. Meta-analysis Of Observational Studies in Epidemiology (MOOSE) group. Jama. 2000;283(15):2008-12.

14. Moher D, Shamseer L, Clarke M, Ghersi D, Liberati A, Petticrew M, et al. Preferred reporting items for systematic review and meta-analysis protocols (PRISMA-P) 2015 statement. Syst Rev. 2015;4(1):1.

15. Met Office. https://www.metoffice.gov.uk/weather/learn-about/weather/seasons/spring/when-does-spring-start. Accessed 9 Sep 2021.

16. Google map. https://www.maps.google.com. Accessed 9 Sep 2021.

17. Stang A. Critical evaluation of the Newcastle-Ottawa scale for the assessment of the quality of nonrandomized studies in meta-analyses. Eur $\mathrm{J}$ Epidemiol. 2010;25(9):603-5.

18. Ali AA, Adam GK, Abdallah TM. Seasonal variation and hypertensive disorders of pregnancy in eastern Sudan. J Obstet Gynaecol. 2015;35(2):153-4.

19. Luo B, Ma X. Risk factors for preeclampsia: a case-control study. Hypertens Pregnancy. 2013;32(4):432-8.

20. Wellington K, Mulla ZD. Seasonal trend in the occurrence of preeclampsia and eclampsia in Texas. Am J Hypertens. 2012;25(1):115-9.

21. Rylander A, Lindqvist PG. Eclampsia is more prevalent during the winter season in Sweden. Acta Obstet Gynecol Scand. 2011;90(1):114-7.

22. Rohr Thomsen C, Brink Henriksen T, Uldbjerg N, Milidou I. Seasonal variation in the hypertensive disorders of pregnancy in Denmark. Acta Obstet Gynecol Scand. 2020;99(5):623-30.

23. Weinberg CR, Shi M, Basso O, DeRoo LA, Harmon Q, Wilcox AJ, et al. Season of Conception, Smoking, and Preeclampsia in Norway. Environ Health Perspect. 2017;125(6):067022.

24. Tran TC, Boumendil A, Bussieres L, Lebreton E, Ropers J, Rozenberg P, et al. Are Meteorological Conditions within the First Trimester of Pregnancy Associated with the Risk of Severe Pre-Eclampsia? Paediatr Perinat Epidemiol. 2015;29(4):261-70.

25. Tam WH, Sahota DS, Lau TK, Li CY, Fung TY. Seasonal variation in pre-eclamptic rate and its association with the ambient temperature and humidity in early pregnancy. Gynecol Obstet Invest. 2008;66(1):22-6.

26. Phillips JK, Bernstein IM, Mongeon JA, Badger GJ. Seasonal variation in preeclampsia based on timing of conception. Obstet Gynecol. 2004;104(5 Pt 1):1015-20.

27. Bullock N, Breese McCoy SJ, Payton ME. Role of race in the seasonality of deliveries with preeclampsia. Med Hypotheses. 2011;77(4):674-6. 
28. Soroori ZZ, Sharami SH, Faraji R. Seasonal variation of the onset of preeclampsia and eclampsia. J Res Med Sci. 2007;12(4):198-202.

29. Makhseed M, Musini VM, Ahmed HA, Abdul Monem R. Influence of seasonal variation on pregnancy-induced hypertension and or preeclampsia. \#N/A. 1999;39(2):196-9.

30. Ros HS, Cnattingius S, Lipworth L. Comparison of risk factors for preeclampsia and gestational hypertension in a population-based cohort study. Am J Epidemiol. 1998;147(11):1062-70.

31. Jamelle RN. Eclampsia: is there a seasonal variation in incidence? J Obstet Gynaecol Res. 1998;24(2):121-8.

32. Magnus P, Eskild A. Seasonal variation in the occurrence of pre-eclampsia. Bjog. 2001;108(11):1116-9.

33. Rudra CB, Williams MA. Monthly variation in preeclampsia prevalence: Washington State, 1987-2001. J Matern Fetal Neonatal Med. 2005;18(5):319-24.

34. Xiong T, Chen P, Mu Y, Li X, Di B, Li J, et al. Association between ambient temperature and hypertensive disorders in pregnancy in China. Nat Commun. 2020;11(1):2925.

35. Goldenberg RL, Culhane JF, lams JD, Romero R. Epidemiology and causes of preterm birth. Lancet. 2008;371(9606):75-84.

36. Hoffman MK, Goudar SS, Kodkany BS, Metgud M, Somannavar M, Okitawutshu J, et al. Low-dose aspirin for the prevention of preterm delivery in nulliparous women with a singleton pregnancy (ASPIRIN): a randomised, double-blind, placebo-controlled trial. Lancet. 2020;395(10220):285-93.

37. Shulman JP, Weng C, Wilkes J, Greene T, Hartnett ME. Association of Maternal Preeclampsia With Infant Risk of Premature Birth and Retinopathy of Prematurity. JAMA Ophthalmol. 2017;135(9):947-53.

38. Lowensohn RI, Stadler DD, Naze C. Current Concepts of Maternal Nutrition. \#N/A. 2016;71(7):413-26.

39. Mirzakhani H, Litonjua AA, McElrath TF, O'Connor G, Lee-Parritz A, Iverson R, et al. Early pregnancy vitamin D status and risk of preeclampsia. J Clin Invest. 2016;126(12):4702-15.

40. Horton-French K, Dunlop E, Lucas RM, Pereira G, Black LJ. Prevalence and predictors of vitamin D deficiency in a nationally representative sample of Australian adolescents and young adults. Eur J Clin Nutr. 2021:1-10.

41. Elongi JP, Tandu B, Spitz B, Verdonck F. [Influence of the seasonal variation on the prevalence of pre-eclampsia in Kinshasa]. Gynecol Obstet Fertil. 2011;39(3):132-5.

42. Wacker J, Schulz M, Frühauf J, Chiwora FM, Solomayer E, Bastert G. Seasonal change in the incidence of preeclampsia in Zimbabwe. Acta Obstet Gynecol Scand. 1998;77(7):712-6.

43. Krininger CE, 3rd, Stephens SH, Hansen PJ. Developmental changes in inhibitory effects of arsenic and heat shock on growth of pre-implantation bovine embryos. Mol Reprod Dev. 2002;63(3):335-40.

44. Aardenburg R, Spaanderman ME, Ekhart TH, van Eijndhoven HW, van der Heijden OW, Peeters LL. Low plasma volume following pregnancy complicated by pre-eclampsia predisposes for hypertensive disease in a next pregnancy. Bjog. 2003;110(11):1001-6.

45. Alba BK, Castellani JW, Charkoudian N. Cold-induced cutaneous vasoconstriction in humans: Function, dysfunction and the distinctly counterproductive. Exp Physiol. 2019;104(8):1202-14.

46. Sibai B, Dekker G, Kupferminc M. Pre-eclampsia. Lancet. 2005;365(9461):785-99.

\section{Figures}



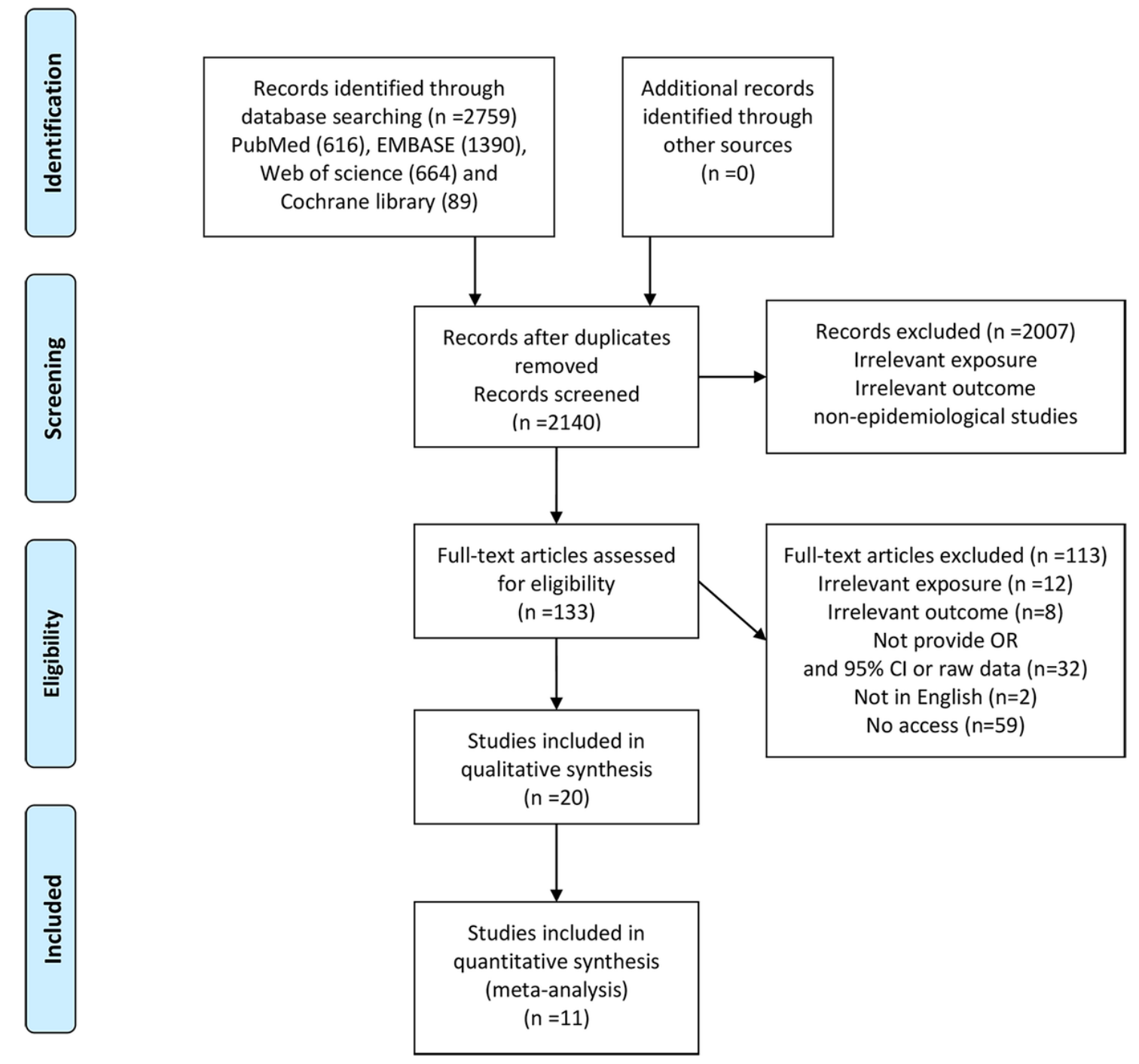

Figure 1

PRISMA flow diagram of study process. 


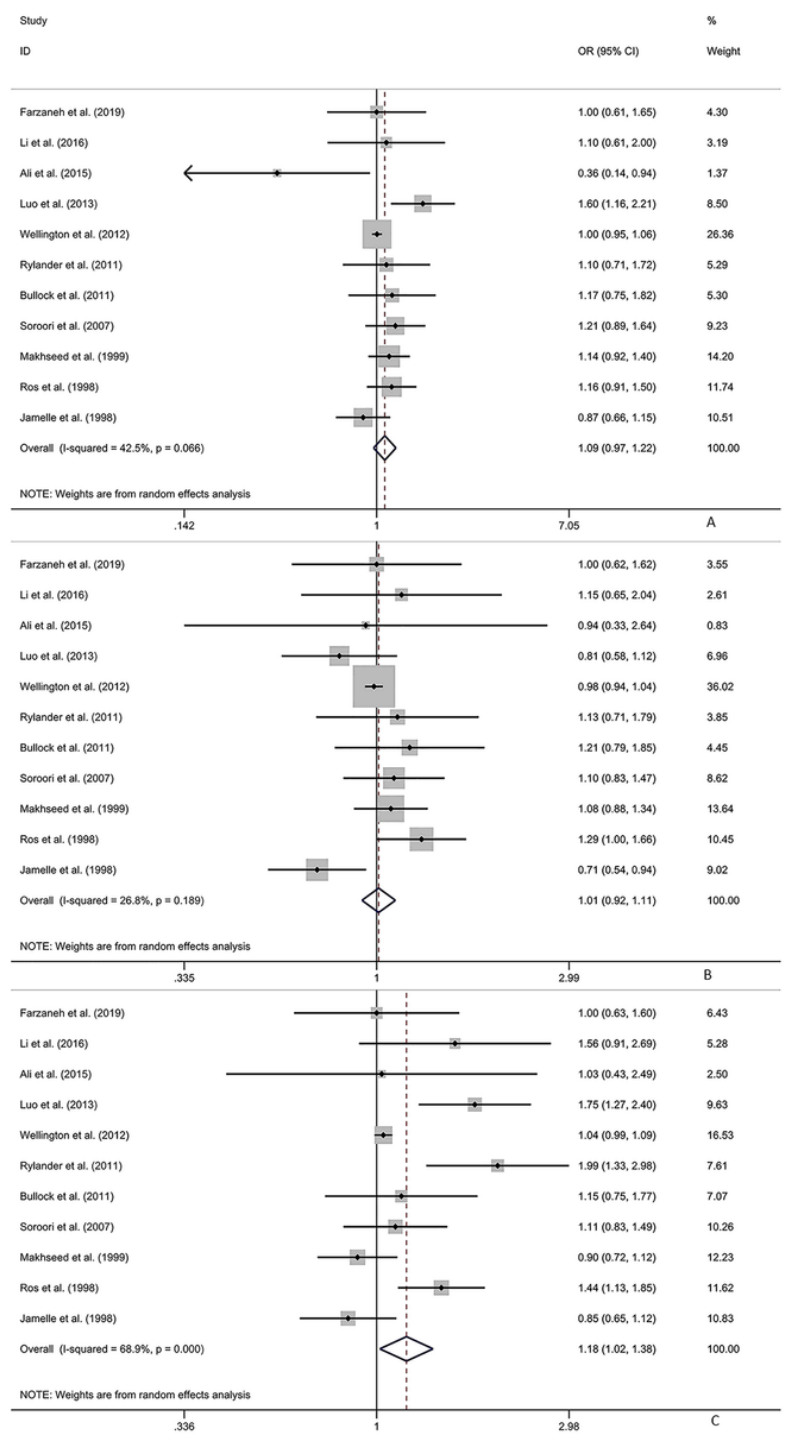

Figure 2

The forest plots show the association between HDP and delivery season. Spring (A), Autumn (B), Winter (C) compared with summer as reference. 
OR $(95 \% \mathrm{Cl}) \quad$ Weight

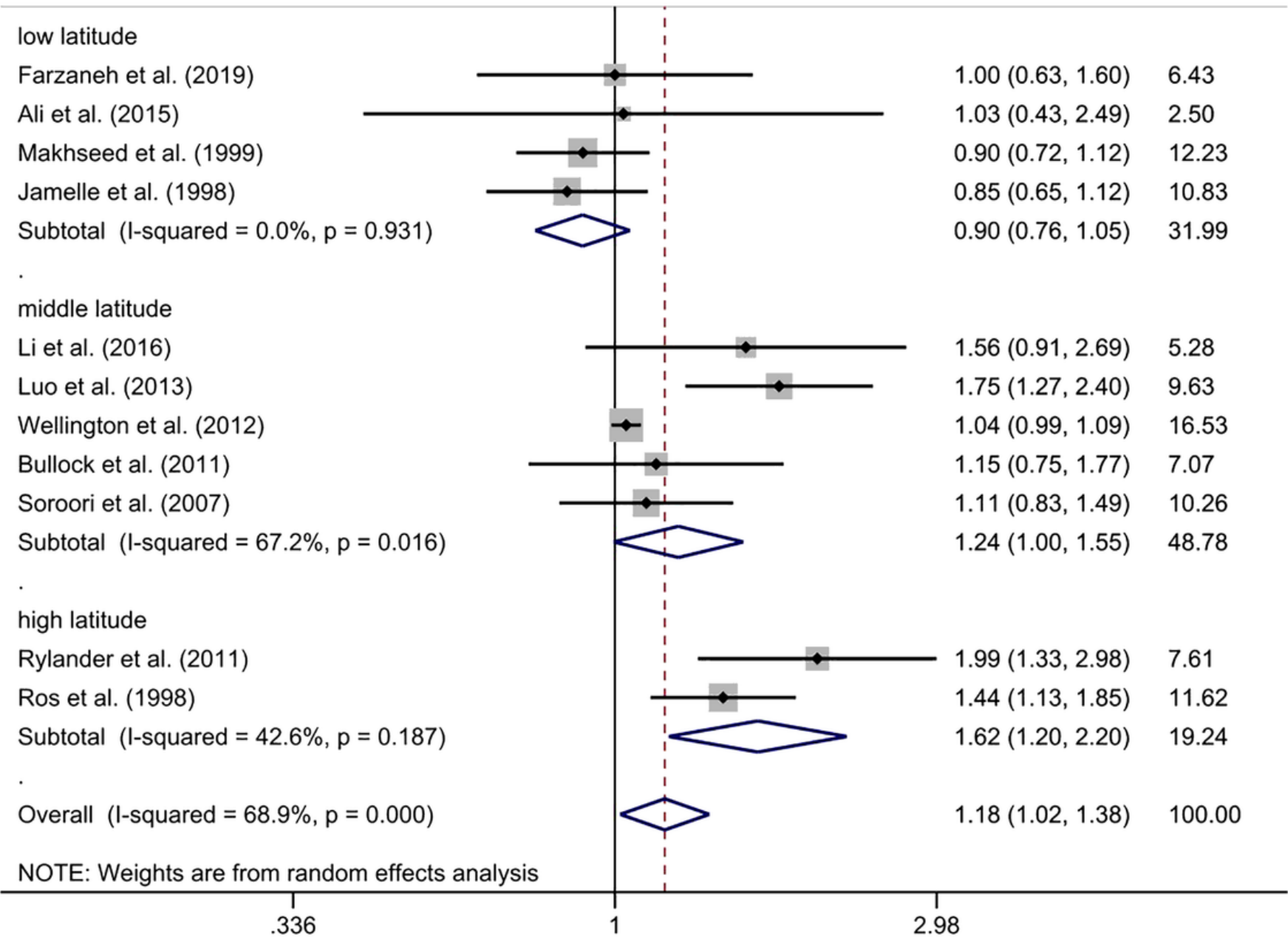

Figure 3

Forest plot of subgroup analysis of HDP and winter delivery compared with summer on latitude. 


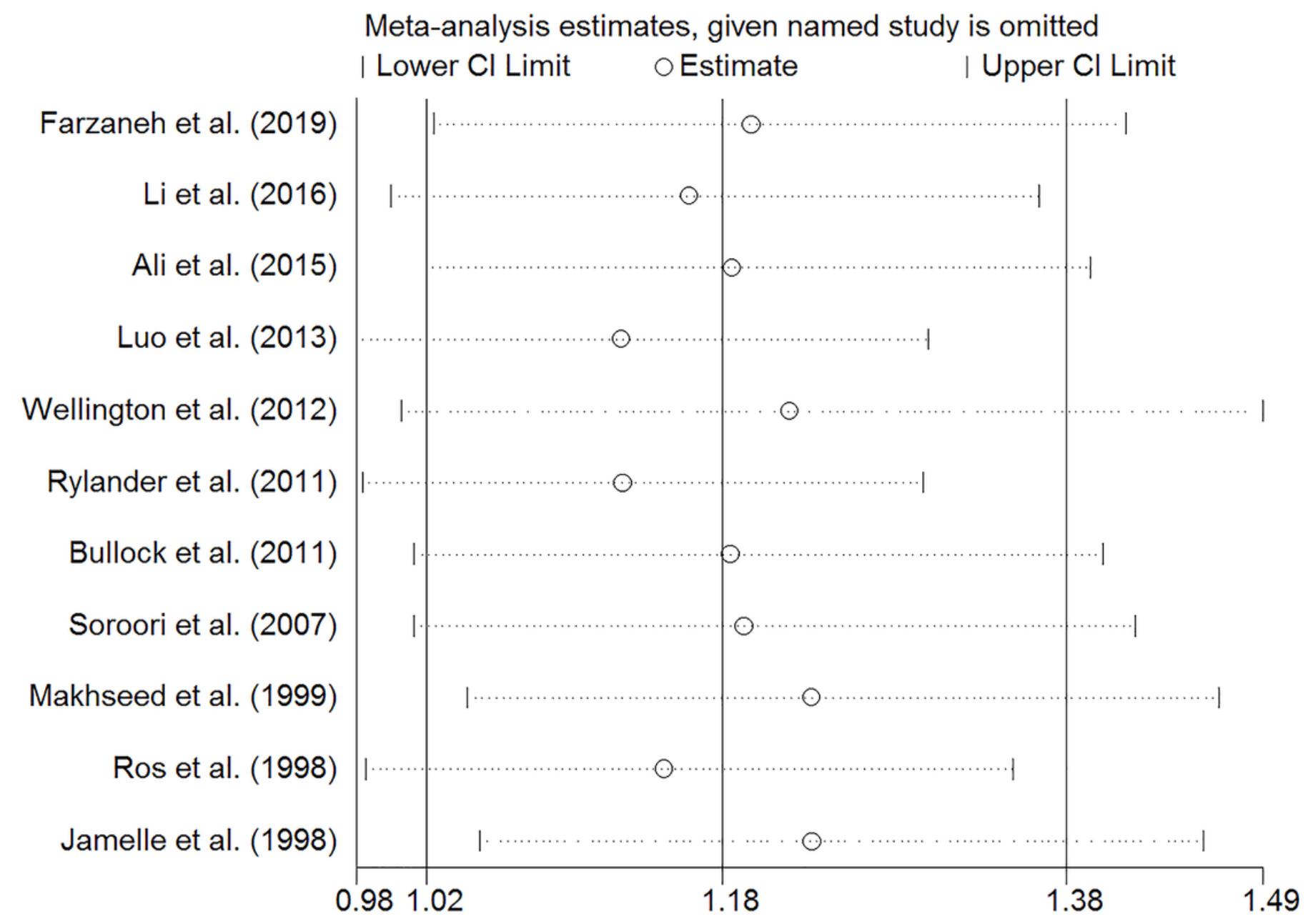

Figure 4

Sensitivity analysis of HDP and winter delivery compared with summer. 
Begg's funnel plot with pseudo 95\% confidence limits

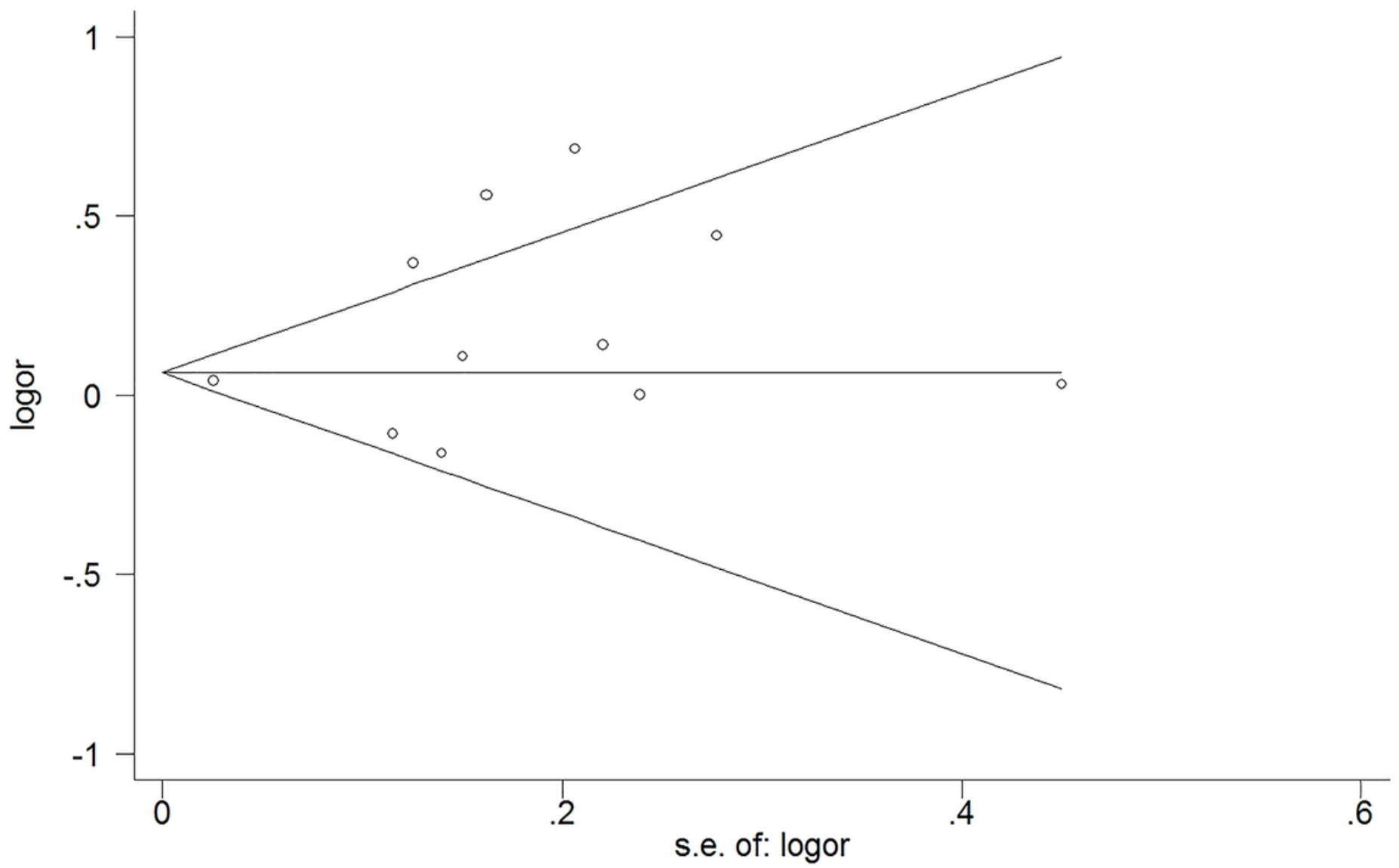

Figure 5

Begg's funnel plot of HDP and winter delivery compared with summer. 


\begin{tabular}{|c|c|c|}
\hline \multirow{2}{*}{ Farzaneh et al. (2019) } & \multirow[b]{2}{*}{$1.00(0.69,1.45)$} & \multirow{2}{*}{6.77} \\
\hline & & \\
\hline Li et al. (2016) & $144(0.94,221)$ & 5.74 \\
\hline & & \\
\hline Ali et al. (2015) & $1.83(1.17,2.89)$ & 5.34 \\
\hline & & \\
\hline Luo et al. (2013) & $1.59(1.23,2.06)$ & 9.37 \\
\hline Wellington et al. (2012) & $1.04(1.00,1.09)$ & 14.45 \\
\hline Rylander et al. (2011) & $1.85(1.37,2.50)$ & 8.28 \\
\hline Bullock et al. (2011) & $1.03(0.72,1.45)$ & 7.21 \\
\hline Soroori et al. (2007) & $1.01(0.80,1.26)$ & 10.23 \\
\hline Makhseed et al. (1999) & $0.84(0.69,1.01)$ & 11.32 \\
\hline Ros et al. (1998) & $1.26(1.04,1.52)$ & 11.23 \\
\hline Jamelle et al. (1998) & $0.99(0.79,1.25)$ & 10.05 \\
\hline Overall $(\mathrm{I}$-squared $=75.4 \%, \mathrm{p}=0.000$ ) & $1.17(1.03,1.34)$ & 100.00 \\
\hline NOTE: Weights are from random effects analysis & & \\
\hline $\begin{array}{c}1 \\
.346\end{array}$ & & \\
\hline
\end{tabular}

\section{Figure 6}

The forest plots show the association between HDP and delivery season: winter delivery compared with other seasons. 